\title{
Interleukin 12 Exerts a Differential Effect on the Maturation of Neonatal and Adult Human CD45RO- CD4 T Cells
}

\author{
Uno Shu, * Christian E. Demeure, * Dae-Gyoo Byun, * Frank Podlaski,‡ Alvin S. Stern," and Guy Delespesse* \\ *University of Montreal, Notre-Dame Hospital Research Center, Montreal, H2L 4 M1 Canada; \\ and ${ }^{\ddagger}$ Hoffmann-La Roche, Nutley, New Jersey 07110-1133
}

\begin{abstract}
It is now recognized that $\mathrm{LL}-12$ plays a predominant role in protective immunity against intracellular pathogens by promoting the development of $T$ helper type 1 (Th1) responses. We here report the unexpected observations that IL-12 exerts differential effects on the maturation of "naive" human CD4 $\mathrm{T}$ cells isolated from umbilical cord blood or from the blood of healthy adults. After priming in the presence of IL-12, naive cells of adult donors, defined as $\mathrm{CD} 5 \mathrm{RO}^{-} \mathrm{CD}^{+} \mathrm{T}$ cells, acquire a Th1 phenotype whereas neonatal cells develop into effector cells producing high levels of $\mathrm{IL}-4$ in addition to IFN- $\gamma$. This effect of $I L-12$ on neonatal $\mathbf{T}$ cells is direct inasmuch as it is observed on highly purified CD4 T cells, however, it is not inhibited by CD8 T cells and natural killer cells. Unstimulated neonatal $T$ cells which have been preincubated with $\mathrm{IL-12}$ before the priming behave like adult $T$ cells and acquire a Th1 phenotype after stimulation in the presence of $\mathrm{L}-12$. Given that $I L-4$ is a potent antagonist of Th1 responses, the finding that $\mathrm{IL}$ 12 promotes the maturation of neonatal $T$ cells into $I L-4$ producers may explain the increased susceptibility of neonates to intracellular pathogens and should be taken into account for the development of vaccines to be used in the perinatal period. (J. Clin. Invest. 1994. 94:1352-1358.) Key words: interleukin $12 \cdot$ interleukin $4 \cdot$ interferon $\gamma \cdot$ neonatal $\mathbf{T}$ lymphocytes $\cdot$ adult naive $\mathbf{T}$ lymphocytes
\end{abstract}

\section{Introduction}

The array of cytokines produced by $\mathrm{T}$ helper cells largely determines the protective value of the immune response. For example, Thelper type 1 (Th1) ${ }^{1}$ cells (producing high levels of IFN$\gamma$ and no IL-4) confer resistance against pathogens with an obligatory or facultative intracellular cycle, whereas Th2 cells (producing high levels of IL-4 and little or no IFN- $\gamma$ ) are

\footnotetext{
Address correspondence to Dr. G. Delespesse, Notre-Dame Hospital Research Center, Allergy Research Laboratory, 1560 Sherbrooke Street East, Montreal, Quebec, H2L 4M1 Canada. 1994. Received for publication 29 March 1994 and in revised form 9 June
}

1. Abbreviations used in this paper: CBMC, cord blood mononuclear cells; NK, natural killer; PE, phycoerythrin-conjugated; r, recombinant; TCR, T cell receptor; Thl, T helper type 1 .

J. Clin. Invest.

(c) The American Society for Clinical Investigation, Inc.

$0021-9738 / 94 / 10 / 1352 / 07 \quad \$ 2.00$

Volume 94, October 1994, 1352-1358 inefficient and may even aggravate such infections (1-7). The development of a predominantly Th1- or Th2-like immune response is influenced greatly by the cytokines released by cells of the first line of defense of the organism, i.e., phagocytes, natural killer (NK) cells, and perhaps also mast cells/basophils and $\gamma / \delta \mathrm{T}$ cells $(7-12)$. IL-12 is rapidly released together with TNF- $\alpha$, IL- 1 , and IL- 6 by phagocytic cells exposed to bacterial or viral antigens (13). These cytokines act in synergy on resting $T$ cells and NK cells to induce IFN- $\gamma$ production, which in turn increases the bactericidal activity of phagocytes $(9,12,14)$. In addition to its important role in natural immunity, IL-12 also promotes the development of $\mathrm{Th} 1$ responses in vivo and in vitro (15-19), an effect which is dependent partly upon its ability to induce IFN- $\gamma$ production $(15,17)$. Treatment of BALB/c mice with exogenous $\mathrm{IL}-12$ at the time of inoculation of the parasite Leishmania major switches their immune response from a Th2 to a Th1 phenotype and confers complete resistance to this otherwise lethal infection $(15,16)$. In vitro, $\mathrm{Ag}$ stimulation of naive $T$ cells from $T$ cell receptor (TCR) transgenic mice in the presence of IL-12 leads to the development of effector cells producing high levels of IFN- $\gamma$ and no IL-4; reciprocally after priming in the presence of $\mathrm{IL}-4$, these TCR transgenic naive $\mathrm{T}$ cells acquire a Th2 phenotype $(17,18$, 20, 21).

In the human system, IL-12 was reported to switch the in vitro recall response of allergen-specific $T$ cells of atopic donors from a Th2- to a Th1-like phenotype (22). Hence, addition of IL-12 to PBMC cultures stimulated with allergen leads to the generation of Th1/Th0, instead of Th2-like allergen-specific T cell lines or clones. In contrast to in vivo observations in mice $(15,16)$, this study suggests that IL-12 has the potential to alter the Th2/Th1 balance of an established immune response. It may act either by converting the phenotype of individual allergenspecific $\mathrm{T}$ cells or by selectively promoting the expansion of preexisting allergen-specific Th $1 /$ Th 0 cells. More recent studies have examined the effect of IL-12 on immunologically naive human CD4 T cells isolated from umbilical cord blood (2325 ). IL-12 not only induces IFN- $\gamma$ and lymphotoxin production by resting neonatal CD4 T cells but most interestingly it also "primes" these cells for the release of high levels of IFN- $\gamma$ but not of IL-4 upon primary stimulation (in the absence of exogenous cytokines) (23). In a subsequent study aiming to determine whether IL-4 might exert a similar effect and prime resting neonatal $\mathrm{T}$ cells for the release of Th2 cytokines upon primary activation, it was observed that cells maintained in the presence of $\mathrm{IL}-4$ alone retain the phenotype of naive cells (CD45R0 ${ }^{-} \mathrm{RA}^{\text {high }}$ ) and release moderate amounts of IFN- $\gamma$ but no IL-4 or IL-5 upon primary stimulation. Quite unexpectedly, neonatal $\mathrm{T}$ cells cultured in the presence of both $\mathrm{IL}-4$ and $\mathrm{IL}$ 12 were found to differentiate into effector cells (CD45R0 ${ }^{\text {bright }}$ ) releasing high levels of both $\mathrm{IL}-4$ and IFN- $\gamma$ upon primary 
stimulation in the absence of exogenous cytokines (24). Taken together, these studies indicated that IL-12 may not only promote the expression of IFN- $\gamma$ but also of IL- 4 during the maturation of neonatal human CD4 T cells. It was hypothesized that the paradoxical effects of IL-12, as well as of IL-4, might be accounted for by the resting stage of the cells which were not stimulated via the TCR/CD3 complex at the time of exposure to the cytokines. Indeed, it was subsequently observed that $\mathrm{IL}$ 4 promotes the development of anti-CD3-activated neonatal CD4 T cells into Th2-like effector cells (25). Here we report the unexpected finding that neonatal cells primed in the presence of IL-12 acquire the capacity to produce high levels of IL-4 as well as IFN- $\gamma$. However "naive" CD4 T cells isolated as $\mathrm{CD}^{2} 5 \mathrm{R}^{-} \mathrm{CD}^{+} \mathrm{T}$ cells from the blood of healthy adults develop into typical Th1 cells after priming in the presence of IL-12.

\section{Methods}

Reagents. Human recombinant ( $\mathrm{r}$ ) IL-12 was produced and purified as described (26); its specific activity was $3 \times 10^{8} \mathrm{U} / \mathrm{mg}$, as measured in the human PHA blast proliferation assay (27). Human rIL-4 was a gift of Dr. H. Hofstetter (CIBA-GEIGY, Basel, Switzerland); rIL-1 $\alpha$ and rTNF- $\alpha$ were received from Dr. J. Hakimi (Hoffmann-La Roche, Nutley, NJ); L-leucyl methyl esther (LLME), phorbol myristate acetate (PMA), and ionomycin were from Sigma Immunochemicals (St. Louis, MO); RPMI 1640 culture medium, FCS, penicillin, streptomycin, Lglutamine, and HBSS were purchased from Flow Laboratories, Inc. (McLean, VA). All the fluorochrome-conjugated $\mathrm{mAbs}$ were purchased from Becton Dickinson Canada (Montreal, Canada), including phycoerythrin-conjugated (PE) mouse mAbs to CD3, CD4, CD16, CD20, CD45RO, and CD56 and the control PE-mouse IgG1 and IgG2; anti$\mathrm{CD} 3 \mathrm{mAb}$ (clone 64.1) was obtained from Bristol-Myers Squibb (Seattle, WA); anti-CD28 mAb (clone CLB402) was obtained from Accurate Chemical \& Scientific Corp. (Westbury, NY). The CD32-transfected mouse L cell line (28) was provided by Dr. K. W. Moore (DNAX, Palo Alto, CA).

Purification of cells. Human umbilical cord blood was drawn on heparin before expulsion of the placenta, and cells were prepared as described (23-25). Briefly, mononuclear cells were obtained by centrifugation on Ficoll-Metrizoate gradients and treated with L-leucyl methyl esther to remove monocytes and NK cells. They were enriched in T cells by rosetting with $S$-(2-aminoethyl) isothiouronium bromide (Aldrich Chemical Co., Milwaukee, WI) treated sheep red blood cells, and rosette-forming $(\mathrm{T})$ cells were treated with Lympho-Kwik TH (One Lambda, Canoga Park, CA). Adult CD4 T cells isolated under the same conditions were depleted in $\mathrm{CD}^{2} 5 \mathrm{RO}^{+}$cells by means of a FACSort ${ }^{\circ}$ (Becton Dickinson Canada). To examine the purity of the cellular preparations, cells were stained using optimal concentrations of PE- or FITCconjugated mAbs or isotype-matched control mAbs for $30 \mathrm{~min}$ on ice washed cells were then analyzed by flow cytometry. Neonatal CD4 T cell preparations were $>98 \%$ viable (trypan blue negative), were $>97 \% \mathrm{CD}^{+}$, and were $<1 \% \mathrm{CD}^{+}, \mathrm{CD}^{+} 6^{+}, \mathrm{CD} 19^{+}, \mathrm{CD}^{+} 6^{+}$, or $\mathrm{Fc} \in \mathrm{R} 1^{+}$; adult $\mathrm{CD}_{45 \mathrm{RO}^{-}} \mathrm{CD} 4$ cells were $<1 \% \mathrm{CD}^{2} 5 \mathrm{RO}^{+}$.

Culture conditions. Neonatal CD4 T cells $\left(0.5 \times 10^{6} / \mathrm{ml}\right)$ were cultured in RPMI 1640 medium containing $10 \%$ FCS, $5 \mathrm{mM}$ L-glutamine, $50 \mathrm{IU}$ penicillin $\mathrm{G}$, and $50 \mathrm{mg} / \mathrm{ml}$ streptomycin in 24-well tissue culture plates $(1 \mathrm{ml} /$ well $)$. Anti-CD3 mAb $64.1(50 \mathrm{ng} / \mathrm{ml})$ in the presence of irradiated (6,500 rad) CD32-transfected mouse L fibroblasts $\left(0.25 \times 10^{6} / \mathrm{ml}\right)$ was used to activate the cells; after $3 \mathrm{~d}$, cells were washed and expanded in fresh medium containing $50 \mathrm{IU} / \mathrm{ml}$ of IL-2 in 24-well plates for an additional $4 \mathrm{~d}$. Recovery of viable cells at day 7 was around 10 times $(8-12)$ the initial amount, and viability was $>98 \%$. Washed cells $\left(0.5 \times 10^{6} / \mathrm{ml}\right)$ were restimulated with either anti-CD3 mAb $64.1(50 \mathrm{ng} / \mathrm{ml})$ and anti-CD28 mAb $(0.5 \mu \mathrm{g} / \mathrm{ml})$ immo- bilized on irradiated CD $32^{+} \mathrm{L}$ cells $\left(0.25 \times 10^{6} / \mathrm{ml}\right)$ or with PMA ( 10 $\mathrm{ng} / \mathrm{ml})$ plus ionomycin $(1 \mu \mathrm{g} / \mathrm{ml})$; supernatant was collected after 48 $\mathrm{h}$ for cytokine titration.

Lymphokine measurement. Lymphokines were measured exactly as in our previous studies (23-25) by using two-site sandwich ELISA or $\mathrm{RIA}$, using a mouse mAb as capture antibody $(\mathrm{Ab})$ and either monoclonal or polyclonal $\mathrm{Ab}$ for detection. Capture mAb to IL-4 (clone $3 \mathrm{H} 4$ ) and IFN- $\gamma$ (clone 42103) are kind gifts of Dr. C. Heusser (CIBAGEIGY). Polyclonal rabbit anti-IL- 4 and IFN- $\gamma$ have been produced and used as described previously (24). IL-5 and IL-10 were measured by means of commercially available mAbs (Cedarlane Laboratories, Ltd., Hornby, Ontario, Canada).

Statistical analysis. Data were analyzed by the Wilcoxon signed rank test by using the Epistat software (Epistat Services, Richardson, TX).

\section{Results}

Cytokine production by neonatal CD4 $T$ cells primed in the presence of exogenous $I L-12$. Highly purified neonatal CD4 T cells were stimulated for $3 \mathrm{~d}$ with anti-CD3 mAb presented on CD32 L cell transfectants in the presence of either IL-12 (50 $\mathrm{pM})$, IL-4 (10 $\mathrm{ng} / \mathrm{ml})$, or in culture medium alone; T cells were then washed and expanded for $4 \mathrm{~d}$ in culture medium supplemented with IL-2 (50 U/ml). Primed cells were washed and stimulated for $48 \mathrm{~h}$ with anti-CD3 plus anti-CD28 mAbs (Fig. $1 A$ ) or with PMA plus ionomycin (Fig. $1 B$ ) to examine their cytokine production. As seen, cells primed in the presence of IL-12 produce high levels of both IL-4 and IFN- $\gamma$, whereas their production of IL-10 is reduced ( $70 \%$ inhibition, $P<0.01$ ), and that of IL-5 is unchanged. As expected, cells primed in the presence of IL-4 produce less IFN- $\gamma$ and more IL-4. To examine whether NK cells, CD8 T lymphocytes, or accessory cells may inhibit the enhancing effect of IL-12 on the maturation of naive CD4 $\mathrm{T}$ cells into IL-4 producers, unfractionated cord blood mononuclear cells (CBMC) or their fraction comprised of Erosette-forming cells (containing both NK cells and T cells) was primed in the presence or absence of IL-12. After expansion, $\mathrm{CD}^{+} \mathrm{T}$ cells were purified by negative selection and examined for IFN- $\gamma$ and IL-4 production upon stimulation with anti-CD3 plus anti-CD28 mAbs. As seen in Fig. 2, CD4 T cells isolated from primary cultures supplemented with IL-12 produce significantly more IFN- $\gamma$ and IL-4 than those isolated from control cultures, indicating that neither activated CD8 T cells nor NK cells prevent the enhancing effect of IL-12 on the development of IL-4-producing CD4 T cells.

Naive $\mathrm{CD}^{+}$cells isolated from adult PBMC differentiate into Th1-like cells after priming in the presence of $I L-12$. The above results are in sharp contrast with recent reports demonstrating that IL-12 promotes the maturation of naive mouse $\mathrm{T}$ cells into Th1 cells $(17,18)$. Given that in these experiments naive $T$ cells were isolated from the spleen of adult and not of newborn animals, we have next examined the effect of IL-12 on the maturation of naive CD4 T cells isolated from adult PBMC. In the experiments summarized in Fig. 3, CD45RO $\mathrm{CD} 4{ }^{+} \mathrm{T}$ cells purified by negative selection from the blood of healthy adults were used as a source of adult naive $T$ cells. The results clearly indicate that, like their murine counterparts, naive adult $\mathrm{T}$ cells differentiate into Th1-like effectors when primed in the presence of exogenous IL-12, whereas they acquire a Th2-like phenotype after priming in the presence of IL-4. 


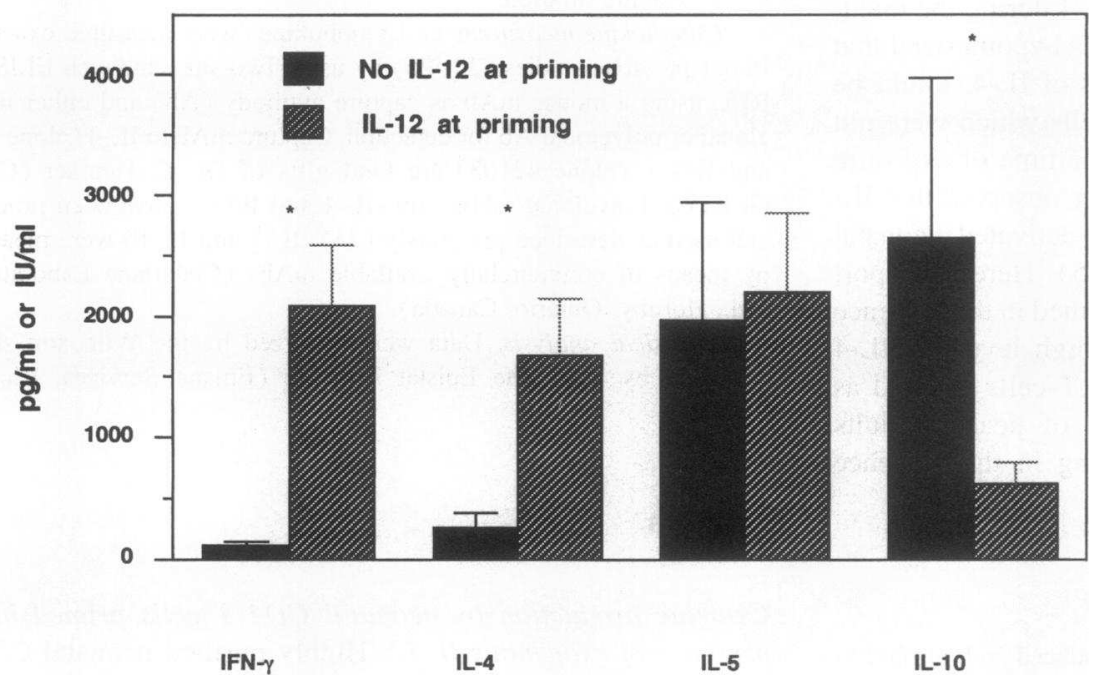

B
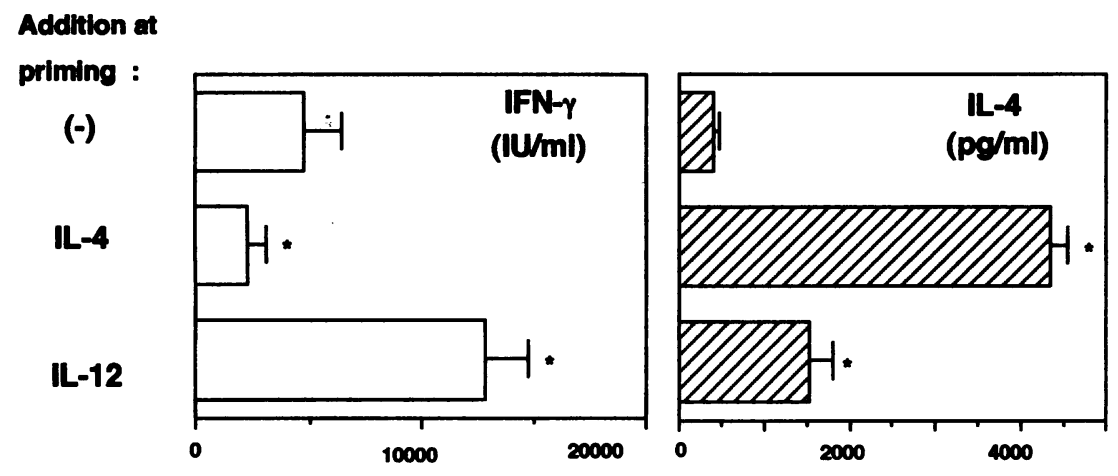

Figure 1. Cells primed in the presence of IL12 develop into high IL-4 producers. Neonatal CD4 $\mathrm{T}$ cells were primed in a two-stage culture: (a) stimulation with anti-CD3 $\mathrm{mAb}$ (64.1) immobilized on CD32-transfected mouse fibroblasts for $3 \mathrm{~d}$ with or without IL$12(50 \mathrm{pM})$ or IL-4 $(10 \mathrm{ng} / \mathrm{ml}) ;$ and $(b)$ after extensive washing, expansion for another $4 \mathrm{~d}$ in culture medium supplemented with IL-2. Cells were then washed and stimulated with either anti-CD3 plus anti-CD28 mAbs on CD32 L transfectants $(A)$ or with PMA plus ionomycin $(B)$. *Different from control cells (primed in the absence of exogenous cytokine) at $P<0.01$. Shown are the mean and standard deviation of five experiments.
Resting neonatal cells preincubated with IL-12 fail to develop into IL-4-producing effector cells. We reported previously that, after preincubation with $\mathrm{IL}-12$, neonatal CD4 T cells become capable of producing high levels of IFN- $\gamma$ but no IL-4 upon primary stimulation in the absence of exogenous cytokine (23). Here we have examined whether preincubation of resting neonatal cells with IL-12 before their activation by anti-CD3 would prevent the development of IL-4-producing cells. To this end, unstimulated CD4 cells were first cultured with or without IL-12 together with IL-1 $(1 \mathrm{ng} / \mathrm{ml})$ and TNF$\alpha(200 \mathrm{ng} / \mathrm{ml})$, which are known to synergize with $\mathrm{IL}-12$ for the induction of IFN- $\gamma$ production (23). At day 3, cultures were supplemented with anti-CD3 $\mathrm{mAb}$ and irradiated CD32transfected fibroblasts; one set of control cultures was also supplemented at this time with IL-12, IL-1, and TNF- $\alpha$. After $3 \mathrm{~d}$ of stimulation with anti-CD3, T cells were collected, expanded in the presence of $\mathrm{IL}-2$, and examined for cytokine production in response to anti-CD3 plus anti-CD28 stimulation. The results clearly indicate that cells which have been preincubated with IL-12 differentiate into Th1-type effector cells after priming in the presence of $\mathrm{IL}-12$ (Fig. 4), whereas, as expected, cells preincubated in culture medium alone and activated in the pres- ence of IL-12 (together with IL-1 and TNF- $\alpha$ ) differentiate into IL-4- and IFN- $\gamma$-producing cells. Moreover, cells preincubated with IL-1 plus TNF- $\alpha$ displayed the same response as control cells preincubated in culture medium alone (data not detailed).

\section{Discussion}

We here report the unexpected finding that IL-12 exerts a differential effect on the maturation of $\mathrm{CD}^{2} 5 \mathrm{RO}^{-} \mathrm{CD} 4 \mathrm{~T}$ cells isolated from umbilical cord blood or from the blood of healthy adults. The present observation that IL-12 directs the development of anti-CD3-activated adult CD45R0 ${ }^{-} \mathrm{T}$ cells into Th1-like cells is in complete agreement with previous studies in the mouse using spleen $T$ cells of young adult animals as a source of naive cells $(17,18)$. Most strikingly, unlike their adult counterparts, neonatal $\mathrm{CD}^{+} \mathrm{T}$ cells primed in the presence of $\mathrm{IL}-12$ produce high levels of IL-4, in addition to IFN- $\gamma$, on restimulation with either PMA plus ionomycin or anti-CD3 plus anti-CD28 mAbs presented on CD32-transfected L fibroblasts. Moreover, these cells produce the same levels of $\mathrm{IL}-5$ but much less $\mathrm{IL}-10$ than control cells primed in the absence of IL-12. This cytokine 


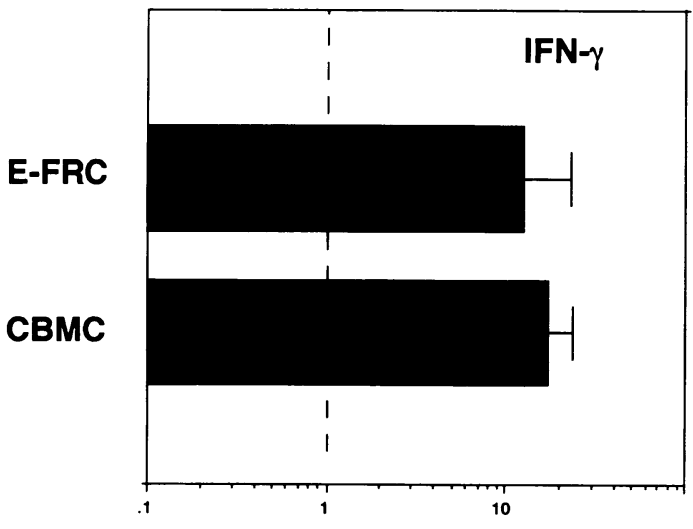

factor increase over control

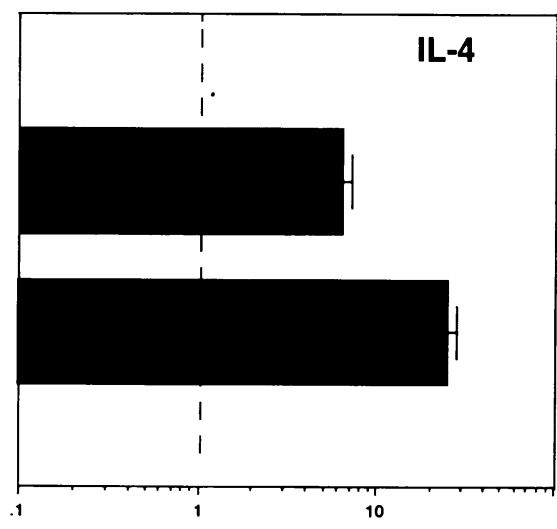

factor increase over control
Figure 2. NK cells and CD8 T cells do not abolish the IL-12-induced expression of IL-4 in neonatal CD4 $\mathrm{T}$ cells. CBMC or Erosette-forming cells ( $E-F R C$ ) were activated for $3 \mathrm{~d}$ with antiCD3, washed, and expanded in IL-2 for $4 \mathrm{~d}$; CD4 $\mathrm{T}$ cells were then obtained by negative selection (Lymphokwik T helper) and examined for cytokine production upon stimulation with anti-CD3 plus anti-CD28 mAbs on CD32 L transfectants. Primed CD4 T cells isolated under these conditions were $>98 \% \mathrm{CD}^{+}$as revealed by flow cytometry analysis. The results of four experiments are ex-

pressed as the mean and standard error of factor increase over the control cultures. Mean and standard error of IFN- $\gamma$ levels in control cultures of PBMC and E-RFC were, respectively, $106 \pm 59$ and $767 \pm 108 \mathrm{IU} / \mathrm{ml}$, and the corresponding levels of IL-4 were $29 \pm 17$ and $163 \pm 113 \mathrm{pg} / \mathrm{ml}$.

profile is similar to that observed upon primary stimulation of neonatal CD4 $\mathrm{T}$ cells after long-term culture in the presence of both IL-4 and IL-12 (24). That IL-12 is capable, under certain circumstances, of enhancing the maturation of naive cells into IL-4 producers was confirmed recently in the mouse system (29). The addition of IL-12 to mouse spleen T cells activated by plastic-bound anti-CD3 in the presence of IL-4 was found to significantly enhance IL-4 production by the primed $\mathrm{T}$ cells without increasing their production of IFN- $\gamma(29)$. The effect of IL-12 on the maturation of neonatal T cells is direct inasmuch as it is observed on highly purified CD4 T cells ( $>99 \% \mathrm{CD}^{-}$, $>97 \% \mathrm{CD}^{+}{ }^{+}$). Of interest, the same effect is also observed if the $\mathrm{CD} 4^{+} \mathrm{T}$ cells are primed in the presence of NK cells and CD8 $\mathrm{T}$ lymphocytes that are known to release high levels of IFN- $\gamma$ in response to IL-12. The data therefore imply that IFN$\gamma$ does not ablate the enhancing effect of IL- 12 on IL- 4 expression by neonatal cells. This view is supported by the previous observation that the addition of neutralizing IFN $-\gamma$ mAb to resting neonatal cells maintained in IL-4 plus IL-12 supplemented medium does not enhance their maturation into high IL-4 producers (24).

Neonatal CD4 T cells are phenotypically and functionally very similar to adult $\mathrm{CD}^{+}{ }^{+} \mathrm{CD} 45 \mathrm{RO}^{-} \mathrm{T}$ cells: $(a)$ they do not respond to soluble Ags; $(b)$ they do not help B cells for Ig production but rather induce suppressor cell activity; $(c)$ on stimulation they release IL-2 but little or no IFN- $\gamma$, IL-4, IL5 , and IL-10; $(d)$ they are homogenously CD45RA ${ }^{\text {high }} / \mathrm{R} 0^{\text {loor - }}$, $\mathrm{CD}_{25}^{-}$, and HLA-DR ${ }^{-}$; and (e) they express the same levels of CD31 $(23,24,30-35)$. These similarities, together with the fact that after activation they both acquire the typical phenotypic and functional features of "memory" $\mathrm{T}$ cells, prompted several investigators to consider that adult and neonatal $\mathrm{CD}_{4}^{+}$ CD45R0 $\mathrm{T}$ cells are immunologically naive or Ag inexperienced $(32,34)$. The finding that IL-12 exerts a differential effect on the maturation of activated neonatal versus adult $\mathrm{CD} 45 \mathrm{R}^{-} \mathrm{T}$ cells indicates that these two types of cells are functionally different and is taken to illustrate the immaturity of umbilical cord blood $\mathrm{T}$ cells. It must be related to recent observations that neonatal $\mathrm{T}$ cells express less CD3 and much more CD38 than adult CD45R0 ${ }^{-}$cells from which however they do not differ by the expression of IL-2, IL-4, and IFN- $\gamma$ mRNA $(30,35-37)$. It is likely that, in the neonates as opposed to the adults, the pool of peripheral $\mathrm{CD}^{+}{ }^{+} \mathrm{T}$ cells contains a large proportion of recent $\mathrm{CD} 4^{+} \mathrm{CD} 8^{-}$thymic emigrants which bear the same levels of CD3 and CD38 and which, upon activation, express the same pattern of cytokine mRNA as umbilical cord blood CD4 T cells $(30,35-37)$. On the other hand, it was argued recently that in the adults the population of CD45R0 $\mathrm{T}$ cells is comprised not only of immunologically naive but also of long-lived memory $\mathrm{T}$ cells which have switched from
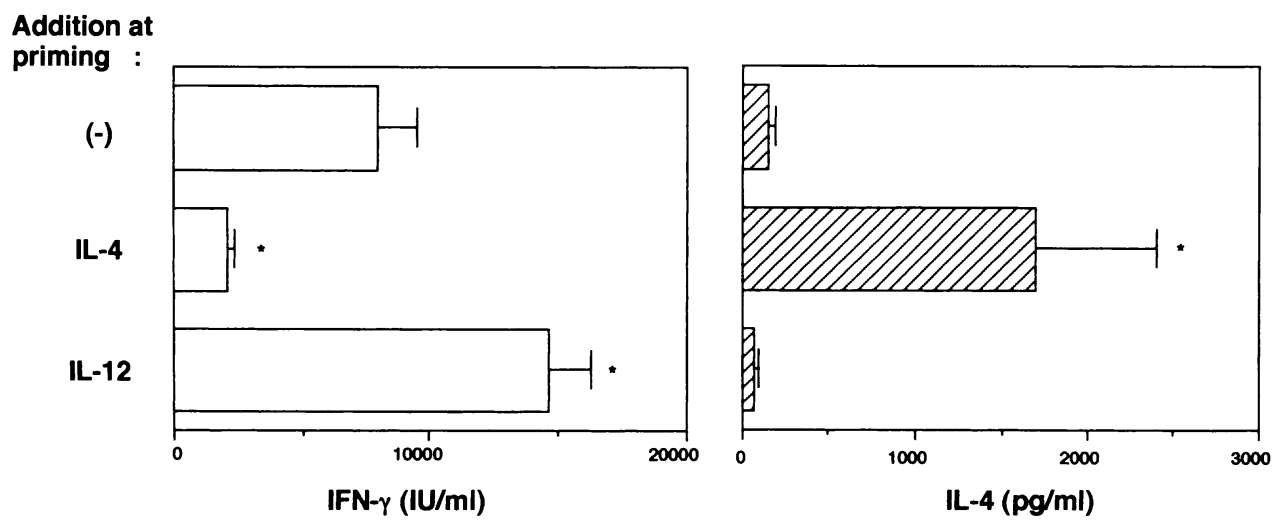

Figure 3. Adult naive CD4 T cells primed in the presence of IL-12 acquire a Th1 phenotype. CD4 T cells from healthy adults were stained with PE-CD45RO mAb, and $\mathrm{CD}^{-15 \mathrm{RO}^{-}}$cells were sorted by means of a FACSort ${ }^{\mathrm{B}}$. Sorted cells $\left(>97 \% \mathrm{CD}^{+},<1 \%\right.$ $\mathrm{CD} 4 \mathrm{RO}^{+}$) were primed and restimulated with PMA plus ionomycin exactly as their neonatal counterparts. Shown are the mean and standard deviation of five experiments. ${ }^{*} P<0.01$. 


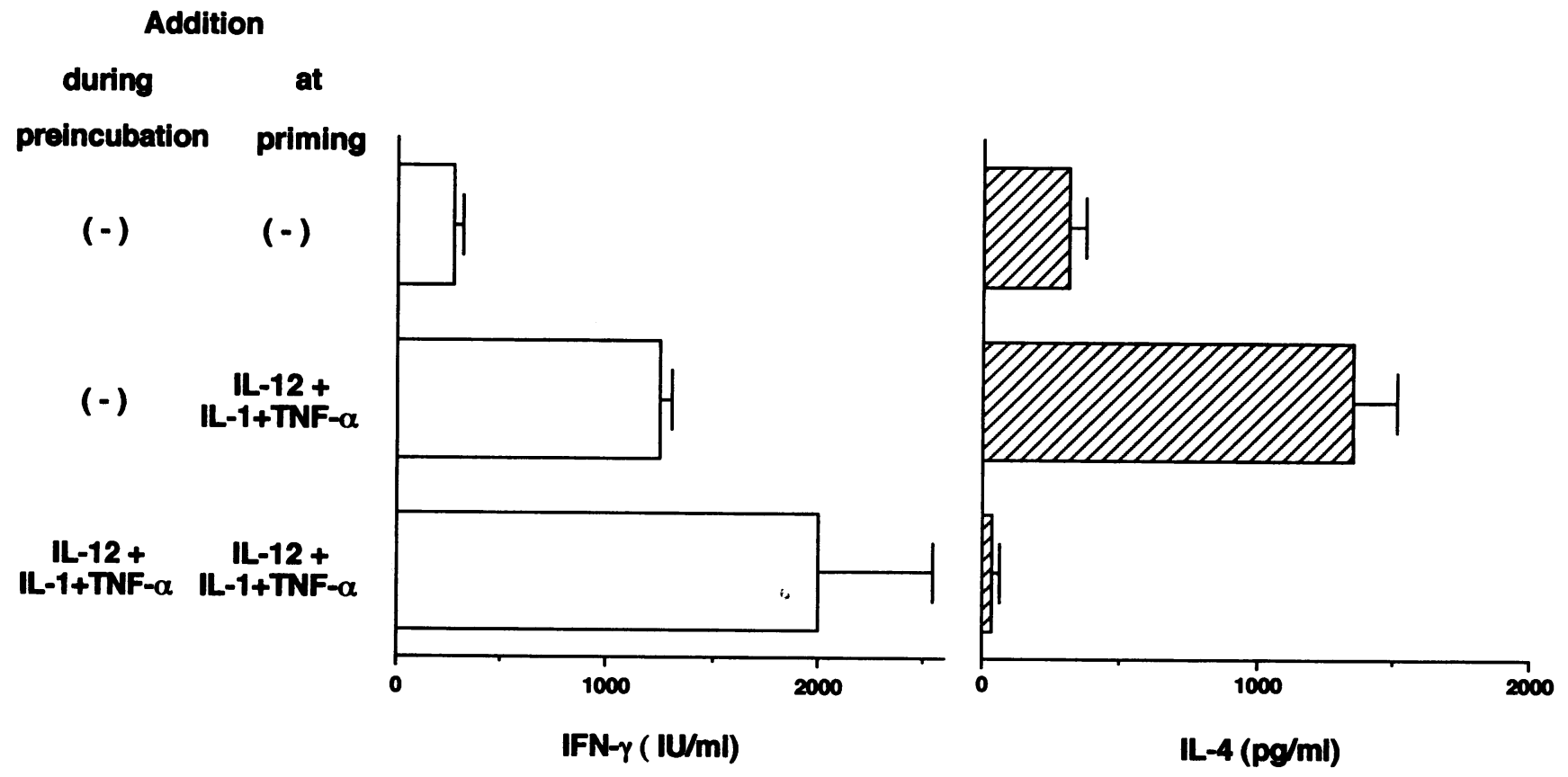

Figure 4. Cells preincubated with IL-12 acquire a Th1 phenotype after priming with anti-CD3. CD4 T cells were cultured either in culture medium alone or in the presence of IL-12 (50 pM) plus IL-1 $(1 \mathrm{ng} / \mathrm{ml})$ plus TNF- $\alpha(200 \mathrm{ng} / \mathrm{ml})$; at day 3, cultures were supplemented with anti-CD3 (final concentration of $50 \mathrm{ng} / \mathrm{ml}$ ) and CD32 L transfectants $\left(0.25 \times 10^{6} /\right.$ well). One set of control cultures (preincubated in culture medium alone) was supplemented with IL-12 plus IL-1 plus TNF- $\alpha$ together with anti-CD3 and fibroblasts. $3 \mathrm{~d}$ after anti-CD3 stimulation, cells were collected, washed, and expanded in IL-2 for $4 \mathrm{~d}$. Cells were then washed and stimulated with anti-CD3 plus anti-CD28 mAbs to measure IL-4 and IFN- $\gamma$ production. Shown are the mean and standard error of four experiments.

$\mathrm{CD}^{2} 4 \mathrm{R}^{+} / \mathrm{RA}^{-}$to $\mathrm{CD}^{-15 \mathrm{R}^{-}} / \mathrm{RA}^{+}(38,39)$. Indeed, such a phenotypic conversion has been observed both in vivo and in vitro $(40-42)$.

The postnatal maturation of $\mathrm{T}$ cells is probably a complex phenomenon which reflects $(a)$ the progressive exposure of the organism to several microbes and antigens; $(b)$ the so-called postthymic maturation of recent thymic emigrants (43); and (c) a drastic change in the hormonal and cytokine milieu to which resting naive $\mathrm{T}$ cells are exposed. Steroid hormones were reported to exert differential effects on the expression of Th1 versus Th2 cytokines (44-46), and maternal lymphocytes recovered from the placental interphase preferentially express Th2-like cytokines (47). Given that IL-12 is produced mainly in response to bacterial antigens (13) and that there is no bacterial colonization during the intrauterine life, it is likely that the production of $\mathrm{IL}-12$ is very low during that period. Supporting the role of the cytokine milieu to which naive cells are exposed before their first encounter with $\mathrm{Ag}$ are the present observations that neonatal cells preincubated with IL-12 before anti-CD3 stimulation respond like adult naive $\mathrm{CD} 4 \mathrm{~T}$ cells on priming in the presence of IL-12 and develop into Th1-like cells.

If applicable in vivo, the finding that IL-12 promotes IL-4 expression in neonatal CD4 $\mathrm{T}$ cells may have considerable clinical implications. Hence, several pathogens which induce a rapid production of $\mathrm{IL}-12$ leading a protective Th1 response in adults would trigger high levels of IL-4 production in neonates. Given that IL-4 inhibits not only the development of Th1 type effector cells but also the release and the function of Th1 cytokines, including the enhancement of macrophage bactericidal activity $(6,48,49)$, the present findings should be related to the in- creased severity or chronicity of certain congenital or perinatal infections. For example, over $90 \%$ of newborns infected with hepatitis B virus develop a chronic infection which is clinically silent but may predispose to the development of hepatocellular carcinoma; in contrast, over $90 \%$ of adults infected with hepatitis B virus develop a Th1-mediated acute inflammatory response resulting in the elimination of the virus $(50,51)$. Similar considerations may explain the severity of neonatal infections with several viruses and bacteria such as herpes simplex virus (52), listeria monocytogenesis (53), and mycobacterium tuberculosis (54). Given that low progression or "resistance" to HIV infection is associated with preferential expression of Th1 cytokines and that, conversely, progression of the disease is associated with dominant expression of $\mathrm{Th} 2$ cytokines, it is reasonable to speculate that the more rapid evolution of neonatal HIV infection is related to the early expression of IL-4 (2). The preventive value of BCG vaccination remains diversely appreciated (54), and it was reported recently that BCG given during the first $3 \mathrm{~d}$ of life is much less efficient and generates more complications than when given after 3 mo (55). These epidemiological findings should be related to our preliminary results showing that the addition of BCG to anti-CD3-activated CBMC leads to the development of CD4 $\mathrm{T}$ cells producing high levels of IL-4.

Finally, the ability of IL-12 to promote IL-4 expression during the priming of neonatal cells may explain the phenomenon of neonatal tolerance to allogeneic cells. Indeed, "tolerant" cells were shown to produce IL- 4 in response to the corresponding allogeneic cells $(56,57)$, and we have observed that IL-12 is produced during primary allogeneic stimulation in vitro (our 
unpublished observations). In conclusion, the present finding that the effect of $\mathrm{IL}-12$ is greatly influenced by the age of the $\mathrm{T}$ cell donor may explain the increased susceptibility of neonates to certain infections and should be taken into consideration for the utilization of vaccines in the neonatal period.

\section{Acknowledgments}

The authors express their gratitude to Dr. M. Gately (Hoffmann-LaRoche) for his critical comments. We are indebted to Dr. P. Raynauld and the nurses at the Obstetrics Department of Notre-Dame Hospital for graciously collecting cord blood samples and to Mrs. R. Beauchemin and F. Lamarre at the Radio-oncology Department for kindly irradiating cells. The secretarial assistance of Norma Del Bosco is greatly appreciated.

This work was supported by an MRC-industry grant (HoffmanLaRoche, Nutley, NJ). G. Delespesse is an MRC Associate.

\section{References}

1. Salgame, P., J. S. Abrams, C. Clayberger, H. Goldstein, J. Convit, R. L. Modlin, and B. R. Bloom. 1991. Differing lymphokine profiles of functional subsets of human CD4 and CD8 T cell clones. Science (Wash. DC). 254:279282.

2. Clerici, M., and G. M. Shearer. 1993. A Th1-Th2 switch is a critical step in the etiology of HIV infection. Immunol. Today. 14:107-112.

3. Sher, A., and R. L. Coleman. 1992. Regulation of immunity to parasites by $\mathrm{T}$ cells and T cell-derived cytokines. Annu. Rev. Immunol. 10:385-409.

4. Heinzel, F. P., M. D. Sadick, B. J. Holaday, R. L. Coffman, and R. M. Locksley. 1989. Reciprocal expression of interferon $\gamma$ or interleukin 4 during the resolution or progression of murine Leishmaniasis. J. Exp. Med. 169:59-72.

5. Peltz, G. 1991 . A role for $\mathrm{CD}^{+}{ }^{+} \mathrm{T}$ cell subsets producing a selective pattern of lymphokines in the pathogenesis of human chronic inflammatory and allergic diseases. Immunol. Rev. 123:23-36.

6. Modlin, R. L., and T. B. Nutman. 1993. Type 2 cytokines and negative immune regulation in human infections. Curr. Opin. Immunol. 4:511-517.

7. Locksley, R. M. 1993. Interleukin 12 in host defense against microbial pathogens. Proc. Natl. Acad. Sci. USA. 90:5879-5880.

8. Romagnani, S. 1992. Induction of Th1 and Th2 responses: a key role for the natural immune response? Immunol. Today. 13:379-383.

9. Trinchieri, G. 1993. Interleukin-12 and its role in the generation of Th1 cells. Immunol. Today. 14:335-339.

10. Haas, W., P. Pereira, and S. Tonegawa. 1993. Gamma/delta cells. Annu. Rev. Immunol. 11:637-686.

11. Seder, R. A., W. E. Paul, A. M. Dvorak, S. J. Scharkis, A. Kagey-Sobotka, J. Niv, F. D. Finkelman, S. A. Barbieri, S. J. Galli, and M. Plaut. 1991. Mouse splenic and bone marrow cell populations that express high affinity Fc $\epsilon$ receptors and produce interleukin 4 are highly enriched in basophils. Proc. Natl. Acad. Sci. USA. 88:2835-2839.

12. Gazzinelli, R. T., S. Hieny, T. A. Wynn, S. Wolf, and A. Sher. 1993. Interleukin 12 is required for the T-lymphocyte-independent induction of interferon $\gamma$ by an intracellular parasite and induces resistance in T-cell-deficient hosts. Proc. Natl. Acad. Sci. USA. 90:6115-6119.

13. D'Andrea, A., M. Rengaraju, N. 'M. Valiante, J. Chehimi, M. Kubin, M. Aste, S. H. Chan, M. Kobayashi, D. Young, E. Nickbarg, et al. 1992. Production of natural killer cell stimulatory factor (interleukin 12) by peripheral blood mononuclear cells. J. Exp. Med. 176:1387-1398.

14. Gately, M. K. 1993. Interleukin-12: a recently discovered cytokine with potential for enhancing cell-mediated immune responses to tumors. Cancer Invest. 11:500-512.

15. Heinzel, F. P., D. S. Schoenhaut, R. M. Rerko, L. E. Rosser, and M. K. Gately. 1993. Recombinant interleukin 12 cures mice infected with Leishmania major. J. Exp. Med. 177:1505-1509.

16. Sypek, J. P., C. L. Chung, S. E. H. Mayor, J. M. Subramanyam, S. J. Goldman, D. S. Sieburth, S. F. Wolf, and R. G. Schaub. 1993. Resolution of cutaneous Leishmaniasis: interleukin 12 initiates a protective $T$ helper type 1 immune response. J. Exp. Med. 177:1797-1802.

17. Hsieh, C. S., S. E. Macatonia, C. S. Tripp, S. F. Wolf, A. O'Garra, and K. M. Murphy. 1993. Listeria-induced Th1 development in $\alpha \beta$-TCR transgenic $\mathrm{CD}^{+} \mathrm{T}$ cells occurs through macrophage production of IL-12. Science (Wash. DC). 260:547-550.

18. Seder, R. A., R. Gazzinelli, A. Sher, and W. E. Paul. 1993. Interleukin 12 acts directly on $\mathrm{CD}^{+} \mathrm{T}$ cells to enhance priming for interferon $\gamma$ production and diminishes interleukin 4 inhibition of such priming. Proc. Natl. Acad. Sci. USA. 90:10188-10192.

19. Morris, S. C., K. B. Madden, J. J. Adamovicz, W. C. Gause, B. R. Hubbard, M. K. Gately, and F. D. Finkelman. 1994. Effects of IL-12 on in vivo cytokine gene expression and Ig isotype selection. J. Immunol. 152:1047-1056.

20. Paul, W. E., R. A. Seder, J. Hu-Li, T. Tanaka, and S. Z. Ben-Sasson. 1992. IL-4 is a major determinant of T cell lymphokine-producing phenotype. In Progress in Immunology VIII. J. Gergely, M. Benczúr, A. Erdei, A. Falus, G. Füst, G. Medgyesi, G. Petrányi, and E. Rajnavölgyi, editors. Springer Hungarica, Budapest. 347-350.

21. Seder, R. A., W. E. Paul, M. M. Davis, and B. Fazekas de St. Groth. 1992. The presence of interleukin 4 during in vitro priming determines the lymphokineproducing potential of $\mathrm{CD}^{+}{ }^{+} \mathrm{T}$ cells from $\mathrm{T}$ cell receptor transgenic mice. J. Exp. Med. 176:1091-1098.

22. Manetti, R., P. Parronchi, M. G. Giudizi, M.-P. Piccinni, E. Maggi, G. Trinchieri, and S. Romagnani. 1993. Natural killer cell stimulatory factor (interleukin 12 [IL-12]) induces T helper type 1 (Th1) specific immune responses and inhibits the development of IL-4-producing Th cells. J. Exp. Med. 177:11991204.

23. Wu, C., C. Demeure, M. Kiniwa, M. Gately, and G. Delespesse. 1993. IL12 induces the production of IFN- $\gamma$ by neonatal human CD4 T cells. J. Immunol. 151:1938-1949.

24. Wu, C. Y., C. E. Demeure, M. Gately, F. Podlaski, H. Yssel, M. Kiniwa, and G. Delespesse. 1993. In vitro maturation of human neonatal CD4 T lymphocytes. I. Induction of IL-4-producing cells after long-term culture in the presence of IL-4 plus either IL-2 or IL-12. J. Immunol. 152:1141-1153.

25. Demeure, C., C. Y. Wu, U. Shu, P. V. Schneider, C. Heusser, H. Yssel and G. Delespesse. 1994. In vitro maturation of human neonatal CD4 T lymphocytes. II. Cytokines present at priming modulate the development of lymphokine production. J. Immunol. 152:4775-4782.

26. Gubler, U., A. O. Chua, D. S. Schoenhaut, C. M. Dwyer, W. McComas, R. Motyka, N. Nabavi, A. G. Wolitzky, P. M. Quinn, P. C. Familletti, and M. K. Gately. 1991. Coexpression of two distinct genes is required to generate secreted bioactive cytotoxic lymphocyte maturation factor. Proc. Natl. Acad. Sci. USA. 88:4143-4149.

27. Stern, A. S., F. J. Podlaski, J. D. Hulmes, Y.-C. E. Pan, P. M. Quinn, A. G. Wolitzky, P. C. Familletti, D. L. Stremlo, T. Truitt, R. Chizzonite, and M. K. Gately. 1990. Purification to homogeneity and partial characterization of cytotoxic lymphocyte maturation factor from human B-lymphoblastoid cells. Proc. Natl. Acad. Sci. USA. 87:6808-6814.

28. Peltz, G. A., M. L. Trounstine, and K. W. Moore. 1988. Cloned and expressed human $\mathrm{Fc}$ receptor for IgG mediates anti-CD3-dependent lymphoproliferation. J. Immunol. 141:1891-1898.

29. Schmitt, E., P. Hoehn, T. Germann, and E. Rüde. 1994. Differential effects of interleukin-12 on the development of naive mouse $\mathrm{CD}^{+} \mathrm{T}$ cells. Eur. $J$. Immunol. 24:343-348.

30. Harris, D. T., M. J. Schumacher, J. Locascio, F. J. Besencon, and E. A Boyse. 1992. Phenotypic and functional immaturity of human umbilical cord blood T lymphocytes. Proc. Natl. Acad. Sci. USA. 89:10006-10013.

31. Torimoto, Y., D. M. Rothstein, N. H. Dang, S. F. Schlossman, and C. Morimoto. 1992. CD31, a novel cell surface marker for CD4 cells of suppressor lineage, unaltered by state of activation. J. Immunol. 148:388-397.

32. Ehlers, S., and K. A. Smith. 1991. Differentiation of T cell lymphokine gene expression: the in vitro acquisition of T cell memory. J. Exp. Med. 173:2536 .

33. Clerici, M., L. DePalma, E. Roilides, R. Baker, and G. M. Shearer. 1993. Analysis of $\mathrm{T}$ helper and antigen-presenting cell functions in cord blood and peripheral blood leukocytes from healthy children of different ages. J. Clin. Invest. 91:2829-2836.

34. Clement, L. T. 1991. Functional and phenotypic properties of "naive" and "memory" $\mathrm{CD}^{+} \mathrm{T}$ cells in the human. Immunol. Res. 10:239-250.

35. Lewis, D. B., C. C. Yu, J. Meyer, B. K. English, S. J. Kahn, and C. B. Wilson. 1991. Cellular and molecular mechanisms for reduced interleukin 4 and interferon- $\gamma$ production by neonatal T cells. J. Clin. Invest. 87:194-202.

36. Gerli, R., P. Rambotti, C. Cernetti, A. Velardi, F. Spinozzi, A. Tabilio, M. Martelli, F. Grignani, and S. Davis. 1984. A mature thymocyte-like phenotypic pattern on human cord circulating T-lymphoid cells. J. Clin. Immunol. 4:461468.

37. Wilson, M., F. S. Rosen, S. F. Schlossman, and E. L. Reinherz. 1985 Ontogeny of human $\mathrm{T}$ and $\mathrm{B}$ lymphocytes during stressed and normal gestation: phenotypic analysis of umbilical cord lymphocytes from term and preterm infants. Clin. Immunol. Immunopathol. 37:1-12.

38. Helbert, M. R., J. L'age-Stehr, and N. A. Mitchison. 1993. Antigen presentation, loss of immunological memory and AIDS. Immunol. Today. 14:340-346.

39. Beverley, P. C. L. 1992. Functional analysis of human T cell subsets defined by CD45 isoform expression. Semin. Immunol. 4:35-41.

40. Rothstein, D. M., A. Yamada, S. F. Schlossman, and C. Morimoto. 1991 
Cyclic regulation of CD45 isoform expression in a long term human CD4 ${ }^{+}$ CD45RA $^{+} \mathrm{T}$ cell line. J. Immunol. 146:1175-1184.

41. Michie, C. A., A. Mclean, C. Alcock, and P. C. L. Beverley. 1992. Lifespan of human lymphocyte subsets defined by CD45 isoforms. Nature (Lond.). 360:264-266.

42. Bell, E. B. 1992. Function of CD4 T cell subsets in vivo: expression of CD45R isoforms. Semin. Immunol. 4:43-51.

43. Stutman, O., and S. T. Ishizaka. 1982. Ontogeny of T-cell function: alloreactivity appears earlier than reactivity against hapten-modified self and interleukin-2 production. Clin. Immunol. Immunopathol. 23:202-211.

44. Daynes, R. A., and B. A. Araneo. 1989. Contrasting effect of glucocorticoids on the capacity of $\mathrm{T}$ cells to produce the growth factors interleukin 2 and interleukin 4. Eur. J. Immunol. 19:2319-2327.

45. Daynes, R. A., D. J. Dudley, and B. A. Araneo. 1990. Regulation of murine lymphokine production in vivo. II. Dehydroepiandrosterone is a natural enhancer of interleukin 2 synthesis by helper T cells. Eur. J. Immunol. 20:793800.

46. Daynes, R. A., B. A. Araneo, T. A. Dowell, K. Huang, and D. Dudley. 1990. Regulation of murine lymphokine production in vivo. III. The lymphoid tissue microenvironment exerts regulatory influences over $\mathrm{T}$ helper cell function. J. Exp. Med. 171:979-996.

47. Lin, H., T. R. Mosmann, L. Guilbert, S. Tuntipopipat, and T. G. Wegmann. 1993. Synthesis of T helper 2-type cytokines at the maternal-fetal interface. $J$. Immunol. 151:4562-4570.

48. Peleman, R., J. Wu, C. Fargeas, and G. Delespesse. 1989. Recombinant interleukin 4 suppresses the production of interferon $\gamma$ by human mononuclear cells. J. Exp. Med. 170:1751-1756.
49. Denich, K., P. Borlin, P. D. O'Hanley, M. Howard, and A. W. Heath. 1993. Expression of the murine interleukin-4 gene in an attenuated aroA strain of salmonella typhimurium: persistence and immune response in BALB/c mice and susceptibility to macrophage killing. Infect. Immun. 61:4818-4825.

50. Margolis, H. S., M. J. Alter, and S. C. Hadler. 1991. Hepatitis B: evolving epidemiology and implications for control. Semin. Liver Dis. 11:84-102.

51. Shapiro, C. N. 1993. Epidemiology of hepatitis B. Pediatr. Infect. Dis. J. 12:433-439.

52. Whitley, R. J. 1992. Neonatal herpes simplex virus infections: pathogenesis and therapy. Pathol. Biol. 40:729-734.

53. Bortolussi, R., and H. P. R. Seelinger. 1990. Listeriosis. In Infectious Diseases of the Fetus and Newborn Infant. W. Lamsback, editor. W. B. Saunders Co., Philadelphia. 812-833.

54. Smith, M., and J. R. Marquis. 1987. Tuberculosis. In Textbook of Pediatric Infectious Diseases. R. D. Feigin and J. D. Cherry, editors. W. B. Saunders Co. Philadelphia. 1362-1369.

55. Ildirim, I., N. Sapan, and B. Cavusoglu. 1992. Comparison of BCG vaccination at birth and at third month of life. Arch. Dis. Child. 67:80-82.

56. Abramowicz, D., P. Durez, C. Gerard, V. Donckier, Z. Amraoui, T. Velu, and M. Goldman. 1993. Neonatal induction of transplantation tolerance in mice is associated with in vivo expression of $\mathrm{IL}-4$ and -10 mRNAs. Transplant. Proc. 25:312-318.

57. Powell, T. J., Jr., and J. W. Streilein. 1990. Neonatal tolerance induction by class II alloantigens activates IL-4-secreting, tolerogen-responsive T cells. $J$. Immunol. 144:854-861. 